\title{
Controls of Organic Carbon and Nutrient Export from Unmanaged and Managed Boreal Forested Catchments
}

\author{
Heidi Aaltonen ${ }^{1, *(\mathbb{D}}$, Tapio Tuukkanen ${ }^{2}{ }^{\mathbb{D}}$, Marjo Palviainen ${ }^{3}{ }^{\mathbb{D}}$, Annamari (Ari) Laurén ${ }^{4}\left(\mathbb{D}\right.$, Sirkka Tattari $^{5}$,

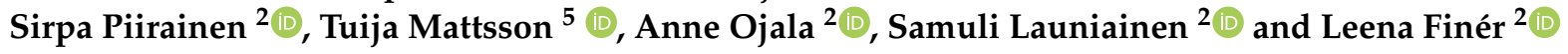 \\ 1 Department of Environmental and Biological Sciences, University of Eastern Finland, P.O. Box 1627, \\ 70211 Kuopio, Finland \\ 2 Natural Resources Institute Finland (Luke), Latokartanonkaari 9, 00790 Helsinki, Finland; \\ tapio.tuukkanen@luke.fi (T.T.); sirpa.piirainen@luke.fi (S.P.); anne.ojala@luke.fi (A.O.); \\ samuli.launiainen@luke.fi (S.L.); leena.finer@luke.fi (L.F.) \\ 3 Department of Forest Sciences, University of Helsinki, P.O. Box 27, 00014 Helsinki, Finland; \\ marjo.palviainen@helsinki.fi \\ 4 School of Forest Sciences, Faculty of Science and Forestry, University of Eastern Finland, P.O. Box 111, \\ Yliopistokatu 7, 80101 Joensuu, Finland; ari.lauren@uef.fi \\ 5 Finnish Environment Institute, Latokartanonkaari 11, 00790 Helsinki, Finland; \\ sirkka.tattari@ymparisto.fi (S.T.); tuija.mattsson@ymparisto.fi (T.M.) \\ * Correspondence: heidi.aaltonen@uef.fi
}

check for updates

Citation: Aaltonen, H.; Tuukkanen, T.; Palviainen, M.; Laurén, A.; Tattari, S.; Piirainen, S.; Mattsson, T.; Ojala,

A.; Launiainen, S.; Finér, L. Controls of Organic Carbon and Nutrient Export from Unmanaged and Managed Boreal Forested Catchments. Water 2021, 13, 2363. https://doi.org/10.3390/w13172363

Academic Editor: Saskia Keesstra

Received: 28 July 2021

Accepted: 25 August 2021

Published: 28 August 2021

Publisher's Note: MDPI stays neutral with regard to jurisdictional claims in published maps and institutional affiliations.

Copyright: (C) 2021 by the authors Licensee MDPI, Basel, Switzerland. This article is an open access article distributed under the terms and conditions of the Creative Commons Attribution (CC BY) license (https:// creativecommons.org/licenses/by/ $4.0 /)$.

\begin{abstract}
Understanding the anthropogenic and natural factors that affect runoff water quality is essential for proper planning of water protection and forest management, particularly in the changing climate. We measured water quality and runoff from 10 unmanaged and 20 managed forested headwater catchments (7-12,149 ha) located in Finland. We used linear mixed effect models to test whether the differences in total organic carbon (TOC), total nitrogen (TN) and total phosphorus (TP) export and concentrations observed can be explained by catchment characteristics, land use, forest management, soil fertility, tree volume and hydrometeorological variables. Results show that much of variation in TOC, TN and TP concentrations and export was explained by drainage, temperature sum, peatland percentage and the proportion of arable area in the catchment. These models explained $45-63 \%$ of variation in concentrations and exports. Mean annual TOC export in unmanaged catchments was $56.4 \pm 9.6 \mathrm{~kg} \mathrm{ha}^{-1} \mathrm{a}^{-1}$, while in managed it was $79.3 \pm 3.3 \mathrm{~kg} \mathrm{ha}^{-1} \mathrm{a}^{-1}$. Same values for TN export were $1.43 \pm 0.2 \mathrm{~kg} \mathrm{ha}^{-1} \mathrm{a}^{-1}$ and $2.31 \pm 0.2 \mathrm{~kg} \mathrm{ha}^{-1} \mathrm{a}^{-1}$, while TP export was $0.053 \pm 0.009 \mathrm{~kg} \mathrm{ha}^{-1} \mathrm{a}^{-1}$ and $0.095 \pm 0.008 \mathrm{~kg} \mathrm{ha}^{-1} \mathrm{a}^{-1}$ for unmanaged and managed, respectively. Corresponding values for concentrations were: TOC $17.7 \pm 2.1 \mathrm{mg} \mathrm{L}^{-1}$ and $28.7 \pm 1.6 \mathrm{mg} \mathrm{L}^{-1}$, for TN $420 \pm 45 \mu \mathrm{g} \mathrm{L}^{-1}$ and $825 \pm 51 \mu \mathrm{g} \mathrm{L}^{-1}$ and TP $15.3 \pm 2.3 \mu \mathrm{g} \mathrm{L}^{-1}$ and $35.6 \pm 3.3 \mu \mathrm{g} \mathrm{L}^{-1}$. Overall concentrations and exports were significantly higher in managed than in unmanaged catchments. Long term temperature sum had an increasing effect on all concentrations and exports, indicating that climate warming may set new challenges to controlling nutrient loads from catchment areas.
\end{abstract}

Keywords: forestry; dissolved organic carbon; nitrogen; phosphorus; drainage; water quality

\section{Introduction}

Boreal catchments are mosaics of upland forests, peatlands and water bodies such as streams, ponds, lakes and rivers. Forest management practices impact carbon (C) and nutrient export to aquatic systems [1-4]. The effect of different forest management practices on $\mathrm{C}$, nitrogen $(\mathrm{N})$ and phosphorus $(\mathrm{P})$ export to water courses have been studied extensively during the past decades. Paired catchment studies have shown that clearcutting increases $\mathrm{N}$ and P export to surface waters for several years [5-9]. Some studies have also reported elevated total organic carbon (TOC) and dissolved organic carbon (DOC) concentrations in runoff from clearcut areas [1,7,9-11]. Moreover, site preparation connected to forest regeneration as well as forest fertilization can increase $\mathrm{N}$ and $\mathrm{P}$ export $[12,13]$. The paired 
catchment studies facilitate statistical detection of treatment effects if the response is greater than the intrinsic uncertainty in the experiment [8]. However, less intensive management, and small, long-term effects are easily masked behind the uncertainty of the experiment and it remains unclear how well the results can be generalized outside the study catchments. Assessing the nutrient export from managed boreal catchments is essential, as they not only affect the water quality inside Finland, but also the Baltic Sea. In the Baltic Sea basin 10 Mha of mires (from total of 19.5 Mha) have been drained for forestry [14].

In Finland, one third of forests are located on peatlands; $23 \%$ of total forest area has been drained, mostly during 1960s-1970s [14]. Around the Baltic Sea basin, in total, half of the peatland areas have been drained [13]. Unmanaged peatlands are no longer drained in Finland, but existing ditch networks are maintained. Some studies have reported increases in TN and/or TP concentrations in runoff following ditch network maintenance (DNM) [15,16], but most studies suggest that DNM reduces DOC export [17-19]. It has been a common assumption that after the first-time drainage water quality returns to the background level (i.e., the level prior to operation) over time [20]. However, a recent study [21] suggested that $\mathrm{N}$ and $\mathrm{P}$ concentrations in runoff from old drained peatlands may slowly increase as a function of time. Drainage causes also long-term changes in the quality of organic matter in runoff [22]. There is a clear knowledge gap between the controlled paired catchment studies and monitoring studies concerning response of water quality to long-term effects of drainage and low intensity harvesting such as thinning, small area clear-cutting and partial harvesting. It remains unclear how these effects accumulate over the long time in the catchment scale. This requires more research on $\mathrm{C}$ and nutrient export from catchments under normal forest management and, as a reference from unmanaged catchments.

Catchment scale water quality monitoring studies have shown that $C, N$ and $P$ export can vary markedly among both unmanaged [12,23] and managed forests [12,24], implying that part of the variation in water quality can be attributed to factors independent of forest management. Thus, all sources of DOC should be considered in the catchment level management [25]. Many studies have suggested that large part of the variation in DOC and TOC concentration in runoff can be explained by the peatland percentage in the catchment [26-32]. Other possible drivers for spatial and temporal variation in DOC leaching include temperature [23,33], runoff [23], and atmospheric sulfate and $\mathrm{N}$ deposition [34]. Moreover, factors related to net primary production, e.g., stand age [35], may be linked to DOC leaching [36]. Potential factors related to $\mathrm{N}$ and $\mathrm{P}$ export are also numerous, for instance, tree species, stand volume [23,37], stand age [38,39], site fertility [23], and catchment topography [40,41] have been identified.

Due to the large number of potential explanatory variables and limitations in data availability (either water quality monitoring data or data on catchment properties), comprehensive analyses on the controls of $C$ and nutrient export in boreal forests have remained relatively rare. Furthermore, given that the climate in northern Europe is expected to change towards warmer and wetter, especially for winter and spring, it is increasingly important to understand the combined effects of forest management and the prevailing environmental conditions on water quality. Some climate change induced changes to seasonal variation of nutrient export have already been reported in river catchments [42]. Thus, with advancing climate change, it is essential to gain knowledge also on climatic factors affecting the water quality and nutrient export. This knowledge will be useful, as forestry faces new challenges in finding suitable management practices, even more so as current nutrient load assessments in Finland do not account for climatic drivers [24].

In the present study we analysed water quality data and runoff data from 10 unmanaged and 20 managed forest-dominated headwater catchments in Finland and studied relationships between water quality and export together with land use, tree stand, site and catchment characteristics, and climatic variables. The aims of the study were (1) to determine how much TOC, $\mathrm{N}$ and $\mathrm{P}$ concentrations and export differ between unmanaged and managed forest catchments and (2) to quantify to what extent climatic vari- 
ables, catchment characteristics and anthropogenic impacts explain variations in TOC, $\mathrm{N}$ and $\mathrm{P}$ concentrations and export. The data set covered a large geographical area ( $>900 \mathrm{~km}$ from south to north and $>400 \mathrm{~km}$ from east to west) including both unmanaged and managed catchments with variable properties obtained from high resolution GIS-data $(16 \mathrm{~m} \times 16 \mathrm{~m}$ grid). The runoff and water quality measurements were carried out intensively for several years, thus providing a unique data set. The dataset belongs to a monitoring network for water quality in forested catchments and is available at https://metsainfo.luke.fi/fi/vesistokuormitukset, accessed on 2 August 2021.

\section{Materials and Methods}

\subsection{Study Areas}

The study was conducted in 10 unmanaged and 20 managed forested catchments located across Finland (Figure 1). The catchments represent typical forests and forest management in Finland. In Finland rotation length from planting to harvest is 70-100 years. Forests are typically grown in even aged stands, which are thinned 2-3 times during the rotation before the final harvest. Most abundant species are Scots pine (Pinus sylvestris) and Norway spruce (Picea abies) and birch (Betula sp.). One fourth of the forests are located on drained peatlands where the open ditch drains are typically cleaned 1-2 times per rotation. The area of the catchments ranged from 7 to 12,150 ha. The peatland cover varied from 5 to $48 \%$ in unmanaged and 5 to $67 \%$ in managed catchments. Most of the managed catchments included drained peatlands. Coniferous species, Norway spruce (Picea abies Karsten) and Scots pine (Pinus sylvestris L.), were dominant in all except one catchment, where Silver birch (Betula pendula Roth.) was the most common tree species (Table S1). The total tree volume varied between 25 and $165 \mathrm{~m}^{3} \mathrm{ha}^{-1}$ in managed and between 2 and $174 \mathrm{~m}^{3} \mathrm{ha}^{-1}$ in unmanaged catchments (Table S1, Supplementary Materials). Annual mean air temperature in the catchments ranged from -1.4 to $7.2^{\circ} \mathrm{C}$ over the monitoring period (2014-2018). The daily air temperatures originate from Finnish Meteorological Institute (FMI) data that are interpolated to $10 \times 10 \mathrm{~km}$ raster throughout Finland using existing meteorological stations. Mean annual runoff was $249-493 \mathrm{~mm}$ in unmanaged catchments and $186-503 \mathrm{~mm}$ in managed catchments (data available online at http:/ / kartta.luke.fi/vesidata /, accessed on 2 August 2021). DNM operations were carried out in five catchments during the study period, and the total area of DNM was $<5 \%$ of the catchment area. Forest regeneration was carried out in 14 catchments and fertilization in 2 catchments. The monitoring catchments were established in forest dominated areas, but small patches of arable areas were found in 12 catchments, where their areal share was mostly $<3 \%$. More detailed catchment specific factors, such as tree stand characteristics, land use and management practices are presented in Table S1. 


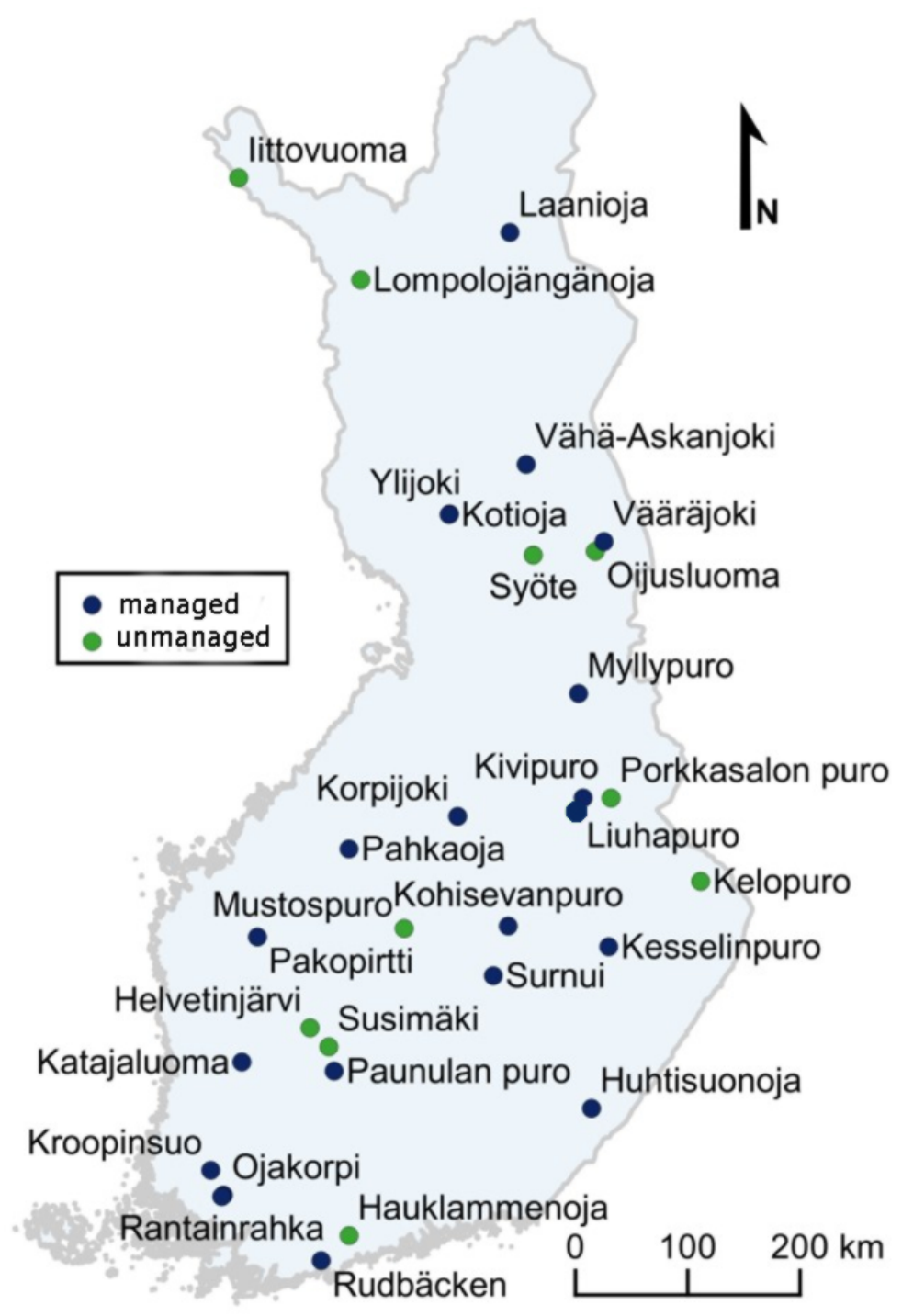

Figure 1. Study catchments containing 10 unmanaged and 20 managed headwater forest catchments.

\subsection{Water Quality Monitoring}

At all catchments discharge at the catchment outlet was monitored continuously using V-notch weirs and automatic water level loggers. Discharge monitoring started in all catchments between January 2014 and June 2014. For this study we included data until the end of 2018. On average, 20 water samples (data available: https:/ / metsainfo.luke.fi/ fi/vesistokuormitukset, accessed on 2 August 2021) were collected from each catchment outlet annually. One sample a week was collected during spring high flows, one sample in two weeks intervals during autumn and once per month for rest of the year. More frequent sampling during high flows than during low flows was used to improve the estimates of annual export loads [43]. The water samples were distributed to regional accredited laboratories (Eurofins laboratoris, www.eurofins.fi/environmentandindustry/ environment/water-analysis/, accessed on 2 August 2021) where samples were analysed for $\mathrm{pH}$, concentrations of unfiltered TOC, total nitrogen (TN), ammonium nitrogen $\left(\mathrm{NH}_{4}\right.$ $\mathrm{N})$, nitrate-nitrite nitrogen $\left(\mathrm{NO}_{2-3}-\mathrm{N}\right)$, total phosphorus (TP) and phosphate-phosphorus $\left(\mathrm{PO}_{4}-\mathrm{P}\right)$. Samples were filtered with Nuclepore polycarbonate filters with $0.4 \mu \mathrm{m}$ pore size. The analyses were done according to SFS EN-ISO standard methods (SFS-EN ISO/IEC 17025:2017) in accredited laboratories. The TOC analyses were done according the standard ISO 10694:1995, SFS-EN 1484:1997 or SFS-EN 13137:2001, TN according the standards SFSEN ISO 11905-1:1998, SFS 5505:1988 or SFS-EN 13652:2002, $\mathrm{NH}_{4}-\mathrm{N}$ according the standards 
SFS 3032:1976, modified ISO 15923-1:2013 or SFS-EN ISO 11732:2005, the sum of $\mathrm{NO}_{3}-\mathrm{N}$ and $\mathrm{NO}_{2}-\mathrm{N}$ according the standards SFS 3029:1976, SFS-EN ISO 13395:1997, modified ISO 15923-1:2013 or SFS-EN ISO 10304-1:2009 (hereafter referred to as $\mathrm{NO}_{3}-\mathrm{N}$ ), TP according the standards SFS-EN ISO 6878:2004 or SFS-EN ISO 15681-2:2005 and $\mathrm{PO}_{4}-\mathrm{P}$ according the standards SFS-EN ISO 6878:2004, SFS-EN ISO 15681-2:2005 or modified ISO 15923-1:2013. More detailed descriptions of the used analysing methods per sample can be found in the open access database Environmental monitoring facilities/inland Waters provided by SYKE (https:/ / www.syke.fi/fi-FI/Avoin_tieto/Ymparistotietojarjestelmat, accessed on 2 August 2021). Respective annual export load of these constituents was computed for period 2014-2018 according to periodic method [24]:

$$
L=F \frac{K}{N} \sum C_{i} Q_{p}
$$

where $L$ is annual load $\left(\mathrm{kg} \mathrm{ha}^{-1} \mathrm{a}^{-1}\right.$ ), $F$ is unit conversion factor for annual loads ( $3600 \mathrm{~s}$ divided by catchment area (ha)), $K$ is length of hourly discharge timeseries, $N$ is number of water samples, $C_{-i}$ instantaneous concentration at time of water sampling $\left(\mathrm{g} \mathrm{L}^{-1}\right)$ and $Q_{p}$ mean discharge $\left(\mathrm{L} \mathrm{s}^{-1}\right)$ between water samplings. Annual mean concentrations were computed by dividing $L$ by total annual runoff.

\subsection{Spatial Data on Catchment Characteristics}

Weather data were acquired from Finnish Meteorological Institutes open data base. The mean long-term temperature sum and annual precipitation were calculated for the catchments from interpolated daily weather time series extending from 1980 to 2019. Topographic/terrain maps by the National Land Survey of Finland were used to determine percentages for arable area, and water bodies in the catchments. Drainage intensity (DI) was computed by dividing the total length of ditches (width $<2 \mathrm{~m}$ ) by the catchment area. Forest stand characteristics within the catchments were obtained from multi-source National Forest Inventory (2013) $16 \mathrm{~m} \times 16 \mathrm{~m}$ raster data [44]. The data contains information about site main class (mineral soil, peatlands) and site fertility class from 1 to 6 . Each raster cell was characterized by stand volume, tree species, site main class (mineral, bog, mire, open peatland) and site fertility class $(1, \ldots, 6$; fertility decreasing with increasing value). For example, proportion of rich peat was calculated as frequency of raster points belonging peatland and site fertility 1 or 2 divided by raster points in the catchment.

\subsection{Statistical Analyses}

Linear mixed effect models (LME) were used for comparisons of annual concentrations and export between unmanaged and managed areas. This was performed with lmer function from lme4-package [45] in R. Multiple comparisons were performed with multcomp package [46]. Measurement year was set as the random factor, while treatment (unmanaged or managed) was set as fixed factor. Concentrations and exports that did not meet the requirements of a parametric test were log transformed. In addition, we created LMEs by using catchment characteristics and weather data to identify the factors that best describe the annual TOC, TN and TP concentrations and export. In this analysis (Equation (2)), measurement year and catchment id were set as the random effect and the fixed effects were arable area, drainage intensity, peat and mineral soil fertility classes, long term temperature sum, annual precipitation, tree volume and management. We used stepwise selection beginning from Equation (2) and progressing based on model Akaike's Information Criterion (AIC) $[47,48]$ and $p$-values of fixed effects. The best model was selected based on lowest AIC value, highest R2 and the significance of the fixed effects. For this, we used the drop 1 function in R [48]. In all the accepted models, the overall $p$-value was $<0.05$, and explanatory variables had a $p$-value of $<0.1$. To avoid multicollinearity, the Variance Inflation Factor (VIF) was calculated and only factors with VIF $<5$ were accepted to the model. 
We chose the potential explanatory variables so that they are not mutually correlated, contain combined ecological and geological information (site fertility in mineral and peat soils, stand volume) and they provide information about management (arable land, drainage, stand volume). The fertility classes also combine ecological and geological information: coarse soils are mostly nutrient poor, while fine soils are nutrient rich. The chosen meteorological factors also carry information of geographical location. The original model was:

$$
\begin{array}{r}
y=a+b_{1} \text { Arable }+b_{2} \text { Drainage }+b_{3}+\text { Rich }_{p}+b_{4}+\text { Poor }_{m}+b_{5} \text { Temp }+ \\
b_{6} \text { Prec }+b_{7} \text { Managed }+b_{8} \text { Tvol }+b_{9}+\text { Peat }_{p}+u_{1}+u_{2}
\end{array}
$$

where $y$ is the dependent factor (TOC, TN or TP export load ( $\left.\mathrm{kg} \mathrm{ha}^{-1} \mathrm{a}^{-1}\right)$ or concentration (mg L ${ }^{-1}$ or $\mu \mathrm{g} \mathrm{L}^{-1}$ ), $a$ is the model intercept, parameters $b_{1}-b_{9}$ are regression coefficients of the fixed factors and $u_{1}$ and $u_{2}$ are the random factors (measurement year, catchment id), Arable is the percentage of arable land in catchment, Drainage is the drainage intensity $(\mathrm{m}$ $\mathrm{ha}^{-1}$ ), Rich $\mathrm{p}$ is ratio of rich peatlands (fertility classes 1-2,) of total catchment area. Poor $\mathrm{m}$ is the ratio of rich mineral soils (fertility classes 1-2 ) of total catchment area. The fertility classes follow the classification presented by Muukkonen and Mäkipää [49]. Temp is the mean long-term temperature sum (1980-2019), Prec is the annual precipitation (mm, 20142018). Managed is a dummy variable with value 1 for managed area and 0 for unmanaged area. Tvol is the mean tree volume $\left(\mathrm{m}^{3} \mathrm{ha}^{-1}\right)$ and Peat $\mathrm{p}$ is the percentage of peatlands in the catchment. Catchment characteristics are presented in Table S1 and the correlations of explanatory variables are presented in Figure S1.

\section{Results}

\subsection{Comparison of Unmanaged and Managed Catchments}

The comparison of TOC, TN and TP concentrations (Figure 2) showed that the concentrations in runoff were consistently higher in managed than in unmanaged catchments $(p<0.001)$. The mean TOC concentration in runoff during the monitoring period for unmanaged catchments was $17.7 \pm 2.1 \mathrm{mg} \mathrm{L}^{-1}$ and $28.7 \pm 1.6 \mathrm{mg} \mathrm{L}^{-1}$ for managed catchments. The mean TN concentrations were $420 \pm 45 \mu \mathrm{g} \mathrm{L}^{-1}$ and $825 \pm 51 \mu \mathrm{g} \mathrm{L}^{-1}$ for unmanaged and managed catchments, while the corresponding values for TP were $15.3 \pm 2.3 \mu \mathrm{g} \mathrm{L}^{-1}$ and $35.6 \pm 3.3 \mu \mathrm{g} \mathrm{L}^{-1}$. Furthermore, the export of TOC, TN and TP were higher for managed than unmanaged areas. The mean TOC export (Figure 3) was $56.4 \pm 9.6 \mathrm{~kg} \mathrm{ha}^{-1} \mathrm{a}^{-1}$ for unmanaged and $79.3 \pm 3.3 \mathrm{~kg} \mathrm{ha}^{-1} \mathrm{a}^{-1}$ for managed catchments. The difference was statistically significant $(p<0.001)$. The managed catchments also had significantly higher TN and TP export than unmanaged catchments $(p<0.001)$. The mean TN export was $1.43 \pm 0.2 \mathrm{~kg} \mathrm{ha}^{-1} \mathrm{a}^{-1}$ for unmanaged and $2.31 \pm 0.2 \mathrm{~kg} \mathrm{ha}^{-1} \mathrm{a}^{-1}$ for managed catchments. TP exports were $0.053 \pm 0.009 \mathrm{~kg} \mathrm{ha}^{-1} \mathrm{a}^{-1}$ and $0.095 \pm 0.008 \mathrm{~kg} \mathrm{ha}^{-1} \mathrm{a}^{-1}$ for unmanaged and managed catchments, respectively.

The managed catchments had significantly higher $\mathrm{PO}_{4}-\mathrm{P}, \mathrm{NO}_{3}-\mathrm{N}$ and $\mathrm{NH}_{4}-\mathrm{N}$ concentrations and export loads than unmanaged catchments $(p<0.001)$. The mean $\mathrm{PO}_{4}{ }^{-}$ $\mathrm{P}$ concentrations were $2.70 \pm 0.5 \mu \mathrm{g} \mathrm{L^{-1 }}$ and $8.09 \pm 0.9 \mu \mathrm{g} \mathrm{L}^{-1}$ for unmanaged and managed catchments, respectively. Mean $\mathrm{NO}_{3}-\mathrm{N}$ concentrations were $51.5 \pm 20 \mu \mathrm{g} \mathrm{L}^{-1}$ and $148 \pm 28 \mu \mathrm{g} \mathrm{L}^{-1}$, whereas mean $\mathrm{NH}_{4}-\mathrm{N}$ concentrations were $8.72 \pm 1.3 \mu \mathrm{g} \mathrm{L}{ }^{-1}$ and $41.4 \pm 6.5 \mu \mathrm{g} \mathrm{L}^{-1}$ for unmanaged and managed catchments, respectively. The $\mathrm{PO}_{4}-\mathrm{P}$ export loads were $0.009 \pm 0.002 \mathrm{~kg} \mathrm{ha}^{-1} \mathrm{a}^{-1}$ and $0.022 \pm 0.002 \mathrm{~kg} \mathrm{ha}^{-1} \mathrm{a}^{-1}$ unmanaged and managed catchments, respectively. The $\mathrm{NO}_{3}-\mathrm{N}$ export loads were $0.20 \pm 0.08 \mathrm{~kg} \mathrm{ha}^{-1} \mathrm{a}^{-1}$ for unmanaged and $0.40 \pm 0.08 \mathrm{~kg} \mathrm{ha}^{-1} \mathrm{a}^{-1}$ for managed, whereas the corresponding values for $\mathrm{NH}_{4}-\mathrm{N}$ were $0.031 \pm 0.00 \mathrm{~kg} \mathrm{ha}^{-1} \mathrm{a}^{-1}$ and $0.098 \pm 0.01 \mathrm{~kg} \mathrm{ha}^{-1} \mathrm{a}^{-1}$. 

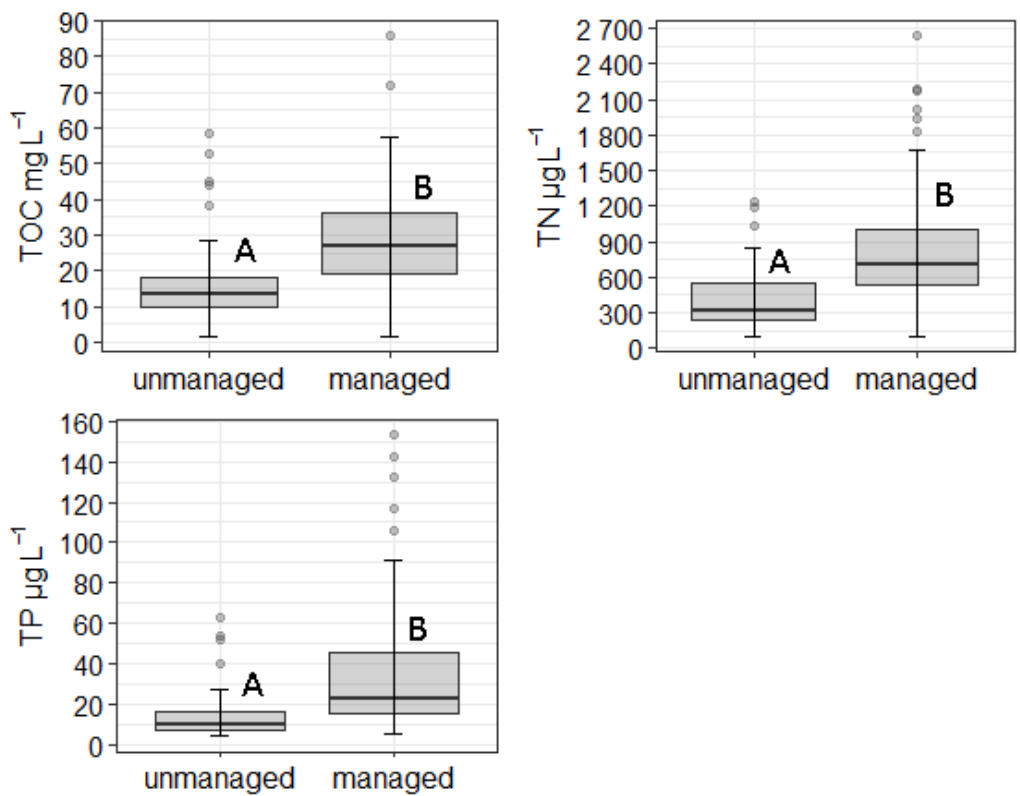

Figure 2. The flow-weighted TOC, TN and TP concentrations in runoff water in unmanaged and managed catchments during the monitoring period (2014-2018). The horizontal line in the box is the median. The boxes indicate the interquartile range while the whiskers show the largest and smallest value within 1.5 times interquartile range, with dots showing observations outside of these. The capital letters denote statistical differences, with different letters indicating a significant difference between unmanaged and managed.
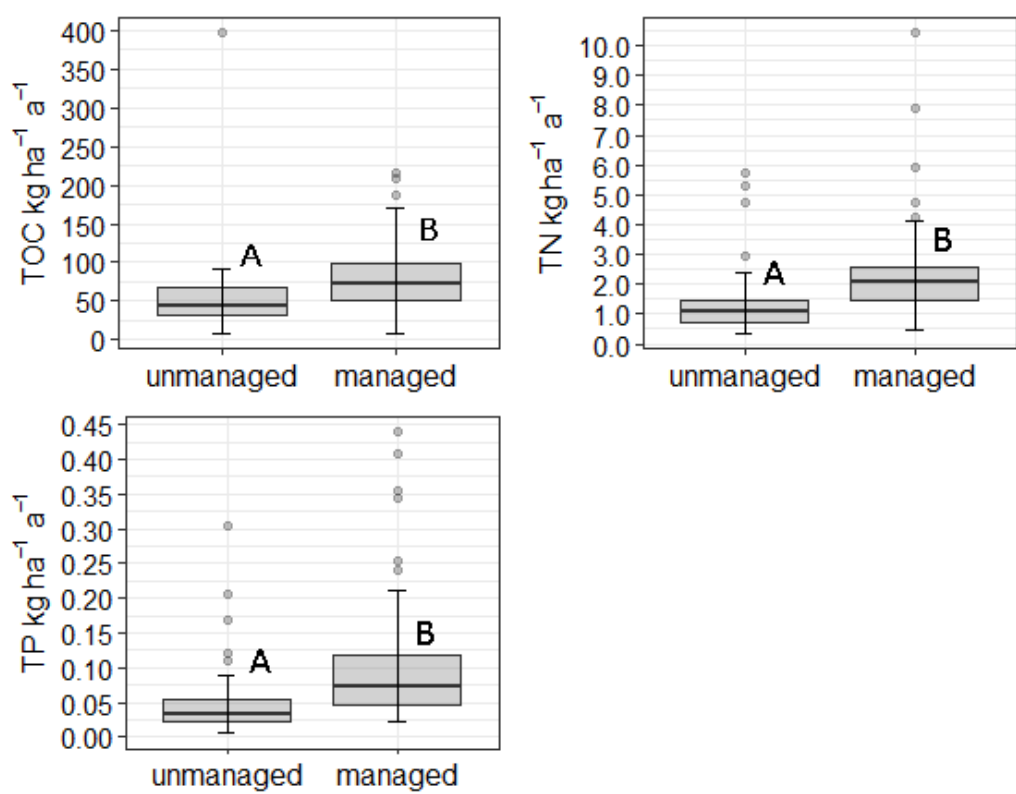

Figure 3. The annual export of TOC, TN and TP in managed and unmanaged catchments over the monitoring period (2014-2018). The horizontal line in the box is the median. The boxes indicate the interquartile range, while whiskers show the largest and smallest value within 1.5 times interquartile range above 75 th percentile and 1.5 times below 25 th percentile, with dots showing observations outside of these. The capital letters denote statistical differences, with different letters indicating a significant difference between unmanaged and managed.

\subsection{Controls of TOC Concentration and Export}

The TOC concentration was most affected by drainage, ratio of rich peatlands, longterm temperature sum and peatland percentage. This model explained $61 \%$ of the variation 
in TOC concentrations (AIC $=993$ ). All of the factors had a positive effect on TOC concentration (Table 1). Likewise the TOC export was best explained by ratio of rich peatlands, temperature sum and peatland percentage, all of which increased TOC export (Table 2). This model explained $48 \%$ of the variation in TOC export (AIC $=1330$ ). The goodness of fit for the models are presented in Figure 4, while the residual plots are presented in Figure S2.
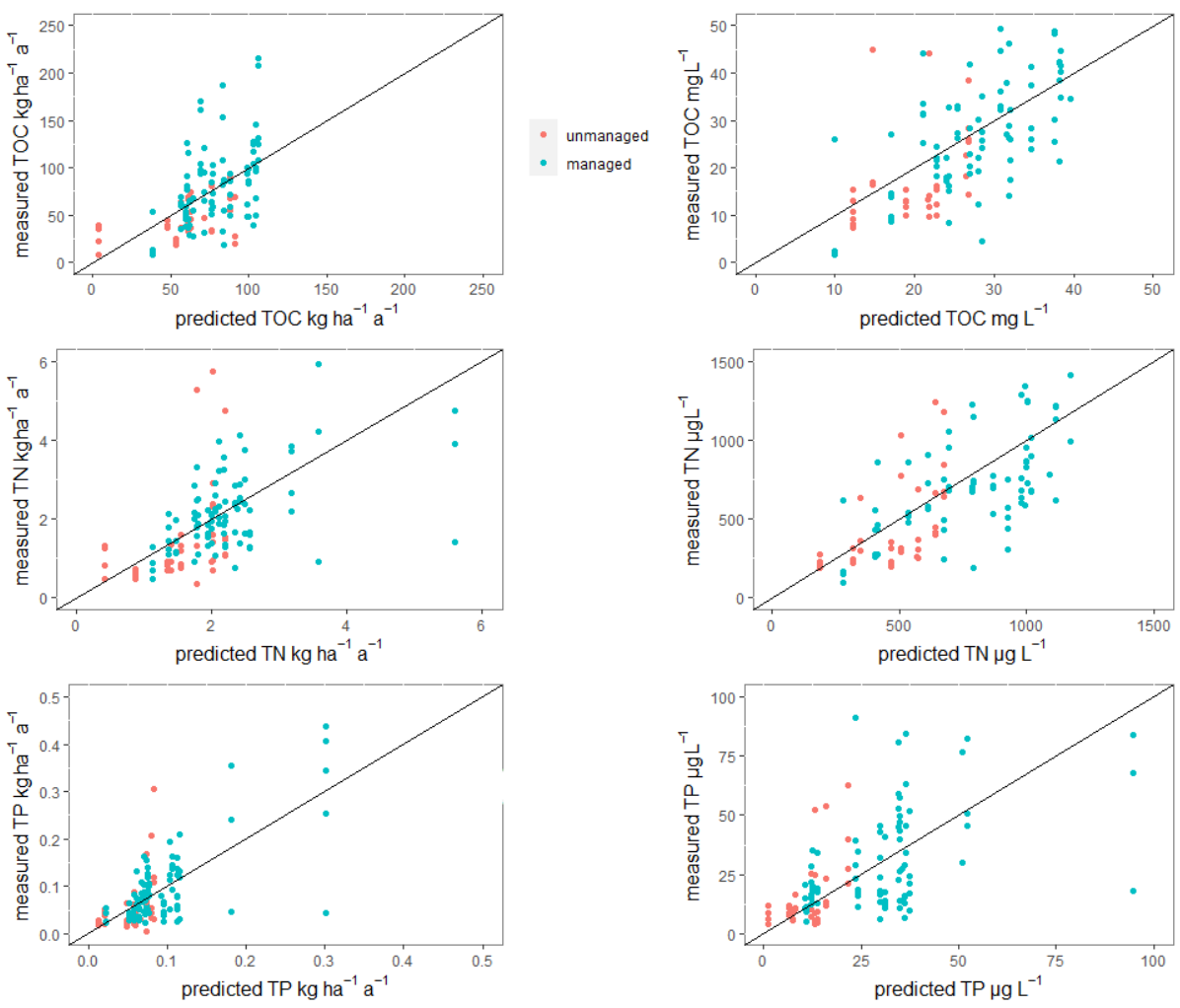

Figure 4. Goodness of fit of the model where predicted values are plotted against measured values.

\subsection{Controls of TN and TP Concentration and Export}

TN concentrations were increased by area of arable lands, drainage, temperature sum and peatland percentage. The model explained $61 \%$ of the variation in TN concentrations $(\mathrm{AIC}=1845)$. Arable area, temperature sum and peatland percentage also increased TN export. This model explained $45 \%$ of variation in TN export (AIC $=397)$.

TP concentrations were best predicted by the proportion of arable land, drainage and temperature sum. These together explained $60 \%$ of variation in TP concentrations $(\mathrm{AIC}=1150)$. Aforementioned variables increased TP concentrations (Table 1). Arable land, ratio of rich peatlands, temperature sum and tree volume increased TP export, while the ratio of poor mineral soils had a decreasing effect (Table 2). These explained $54 \%$ of variation $(\mathrm{AIC}=-364)$. 
Table 1. Parameter estimates of fixed factors of the final models for concentrations.

\begin{tabular}{llll}
\hline $\begin{array}{l}\text { Regression Coefficient of Fixed } \\
\text { Factors ( } \pm \text { TE and } \boldsymbol{p} \text {-Value) }\end{array}$ & TOC Con. & TN Con. & TP Con. \\
$\mathbf{R}^{2}$ & $\mathbf{0 . 6 1}$ & $\mathbf{0 . 6 3}$ & $\mathbf{0 . 6 0}$ \\
Model $\boldsymbol{p}$.Value & $\boldsymbol{p}<\mathbf{0 . 0 1}$ & $\boldsymbol{p}<\mathbf{0 . 0 1}$ & $\boldsymbol{p}<\mathbf{0 . 0 1}$ \\
\hline a intercept & $-22.0 \pm 9.8 p<0.05$ & $-498 \pm 240 p<0.05$ & $-11.7 \pm 13 p=0.4$ \\
b1 Arabl & & $5187 \pm 1763 p<0.05$ & $543 \pm 110 p<0.01$ \\
b2 Drainage & $0.05 \pm 0.0 p=0.1$ & $2.88 \pm 0.9 p<0.01$ & $0.15 \pm 0.1 p<0.05$ \\
b3 Rich & $215 \pm 115 p<0.1$ & & \\
b4 Poor & & & \\
b5 Temp & $0.03 \pm 0.0 p<0.01$ & $0.74 \pm 0.2 p<0.01$ & $0.02 \pm 0.0 p<0.1$ \\
b6 Prec & & & \\
b7 Managed & & & \\
b8 Tvol & & & \\
b9 Peat & & & \\
\hline
\end{tabular}

Table 2. Parameter estimates of fixed factors of the final models for export.

\begin{tabular}{llll}
\hline $\begin{array}{l}\text { Regression Coefficient of Fixed } \\
\text { Factors }( \pm \text { SE and } p \text {-Value) }\end{array}$ & TOC Export & TN Export & TP Export \\
$\mathbf{R}^{2}$ & $\mathbf{0 . 4 8}$ & $\mathbf{0 . 4 5}$ & $\mathbf{0 . 5 4}$ \\
Model $p$.Value & $p<\mathbf{0 . 0 1}$ & $p<0.01$ & $p<0.01$ \\
\hline a intercept & $-41 \pm 35 p<0.2$ & $-0.70 \pm 0.6 p<0.1$ & $-3.08 \pm 0.03 p<0.3$ \\
b1 Arable & & $32.2 \pm 4.0 p<0.01$ & $1.90 \pm 0.2 p<0.01$ \\
b2 Drainage & & & $0.90 \pm 0.5 p<0.1$ \\
b3 Rich & $825 \pm 443 p<0.06$ & & $-0.31 \pm 0.1 p<0.05$ \\
b4 Poor & & & $9.91 \times 10^{-5} \pm 3 \times 10^{-5}$ \\
b5 Temp & $0.07 \pm 0.03 p=0.01$ & $0.002 \pm 0.0 p<0.01$ & \\
b6 Prec & & & \\
b7 Managed & & & $-1.95 \times 10^{-4} \pm 1.1 \times 10^{-4}$ \\
b8 Tvol & & & $p<0.1$ \\
b9 Peat & & & \\
\hline
\end{tabular}

\section{Discussion}

4.1. Carbon and Nutrient Export from Unmanaged and Managed Boreal Catchments

The managed catchments had higher TOC concentrations and export than the unmanaged ones. However, when statistical models were applied, management did not appear among the factors most affecting concentrations and exports. Although seemingly contradictory, this simply implies, that there are other factors (i.e., ratio of rich peatlands, peatland percentage and temperature sum) that have a more profound effect on catchment level export and concentration. For example, the background load of TC from peatlands may be so high, that the effect of management does not necessarily come forward [50] in the stepwise regression. 
The observed mean TOC exports (mean $56.5 \mathrm{~kg} \mathrm{ha}^{-1} \mathrm{a}^{-1}$ ) in unmanaged areas were close to previously reported values (mean $62 \mathrm{~kg} \mathrm{ha}^{-1} \mathrm{a}^{-1}$ ) based on data collected from 21 to 28 pristine Finnish catchments $[23,24,28]$. Two of these studies had more catchments than the present study $[23,28]$, but they had no observations from catchments located in the northernmost parts of Finland where the TOC export is typically low. This may explain the slightly lower TOC export in unmanaged catchments in our study compared to the previous studies. The third study had observations also from northern Finland and very long time series (1982-2018) [24], which could as well explain the differences. In managed catchments, the mean TOC export obtained in our study $\left(79.4 \mathrm{~kg} \mathrm{ha}^{-1} \mathrm{a}^{-1}\right)$ is within the range reported in other boreal catchments $\left(23-148 \mathrm{~kg} \mathrm{ha}^{-1} \mathrm{a}^{-1}\right)$ [4,51].

The statistical comparisons further indicate that TN and TP concentrations and export from managed boreal catchments are higher than those from unmanaged catchments (Figures 2 and 3). TN export from managed catchments $\left(2.3 \mathrm{~kg} \mathrm{ha}^{-1} \mathrm{a}^{-1}\right)$ found in our study is close to the mean value of $1.8 \mathrm{~kg} \mathrm{ha}^{-1} \mathrm{a}^{-1}$ reported previously [10]. Furthermore, for the unmanaged catchments, the range and mean of TN and TP export found in the present study (Figure 3) agree with the previously published values [23,28].

Given the good geographical coverage of our catchments (Figure 1) and the consistent water sampling strategy applied (see Section 2.2), we argue that the data are hitherto the best available for estimation of TOC, $\mathrm{N}$ and $\mathrm{P}$ export from the variety of managed and unmanaged forested catchments in Finland. However, we acknowledge that the time series presented in the study are still relatively short (5 years) and although the data is suitable for comparative purposes, more data needs to be collected and analysed to draw conclusions on the effects of forestry operations to $\mathrm{C}$ and nutrient export.

\subsection{Controls on TOC Export}

The LME showed that $61 \%$ of TOC concentration was explained by ratio of rich peatlands, long-term temperature sum, drainage and peatland percentage, while $48 \%$ of TOC export was explained by the rich peatlands, peatland percentage and temperature sum. The rich peatlands increased the TOC concentrations and export. Rich peatlands often are characterized by Carex peat, which releases more DOC than Sphagnum peat typical in poorer sites [52,53]. Fertile peatlands have been also found to be hotspots for TOC export in subarctic regions [54] and continental climates [32]. A positive correlation between peat coverage and TOC (or DOC) export is well known in many different environments [26-29,31,32], which was also apparent in our TOC models. Opposed to peatlands, mineral soils tend to retain DOC and therefore DOC concentrations in streams do not necessarily reflect the DOC release from organic matter [55].

Furthermore, TOC export and concentrations increased with increasing temperature sum. It has been found that TOC concentration in runoff increases with increasing temperature in undisturbed forests [23]. A positive correlation has also been found with TOC concentration in runoff and mean air temperature in peat extraction areas [56]. However, there are contrasting studies on the overall effect of temperature on decomposition and carbon balance in peat soils $[57,58]$. Nonetheless, warmer climate accelerates decomposition of soil organic matter [59,60], leading to higher release and potential transport of TOC. Supporting this view, previous studies have suggested that the increasing TOC trends have been caused, at least in part, by simultaneous increase in air and stream water temperature [33,61]. It is possible that the ongoing global warming will lead to increasing TOC exports in boreal catchments, as the climate in northern latitudes is predicted to experience the most drastic increases in temperature (IPCC in Climate Change, 2013). There are indications that the terrestrial boreal region is already reacting to ephemeral effects of global warming [62].

The TOC concentrations were increased by drainage intensity as also found by other studies [24]. Drainage is linked to hydrological conditions in the catchment and thus affect leaching [63], resulting in higher leaching of TOC. In less intensively drained areas TOC is not leached readily because organic matter decomposition is slowed down by 
higher water table [64]. While in more intensively drained areas water flow path and water residence time are shorter [65] thus increasing leaching, in less drained sites these are longer, allowing more efficient retention [66] and biodegradation of TOC during the transport [52]. However, some previous studies show no increase in organic carbon release due to drainage $[15,51,67]$. Given that DNM also may reduce DOC leaching [17-19] and that it is usually performed simultaneously to clear-cutting on drained areas (to compensate decreasing transpiration), DNM operations may counterbalance the potential increase in TOC release caused by clear-cutting [7]. For example, Åström et al. noted that after water table lowering the residence time of water in upper organic layers decreases, leading to decreased leaching of soluble matter [17]. At the same time humic substances may be retained in the mineral soil part of the ditches [17].

\subsection{Controls of Nitrogen and Phosphorus Export}

Arable land increased the concentrations and exports of TN and TP. Agriculture is the most significant source of $\mathrm{N}$ to surface waters, especially in the southern and western parts of Finland [68]. The higher $\mathrm{N}$ and $\mathrm{P}$ export and concentrations connected to arable lands are most commonly related to fertilization $[10,13,69]$. The results indicate that even a small proportion of arable land in catchment area, where management operations (fertilization, soil preparation etc.) are done yearly, can markedly increase TN and TP exports from the whole catchment [70]. Furthermore, temperature sum had an increasing effect on TN and TP concentrations and exports, likely because higher temperature increases biomass production, organic matter decomposition and the length of growing season. Of the biomass related factors in the model, only TP export was affected (decreased) by the tree volume, probably caused by P uptake by trees. Previously, it has been shown that forest harvesting increases labile P sources in soil [71]. Further, temperature sum is not only linked to the biomass production and growing season length, but also to the geographical location of the catchment.

Ratio of rich peatlands had an increasing effect on TP export, while TN concentrations were increased by the total peatland coverage. Fertile peatlands contain large nutrient stocks which are potentially subjected to leaching [72]. Peat accumulation on fens has been found to control the long-term P storage [73], whereas nutrient poor peatlands are prone to $\mathrm{P}$ leaching [74]. Iron and aluminium in peat can decrease $\mathrm{P}$ leaching [75], and poor peatlands have very low concentrations of $\mathrm{Fe}$ and $\mathrm{Al}$, and therefore, may actually have higher P leaching than fertile sites [76]. Positive correlation between soil fertility and $\mathrm{N}$ leaching have been previously shown to occur among unmanaged boreal forests [23] and among drained peatland forests [15]. Other studies have suggested that peatland coverage per se is important for determining $\mathrm{N}$ and $\mathrm{P}$ losses from forested catchments $[61,77,78]$. In addition, increasing ratio of poor mineral soils decrease TP export. P stocks in poor mineral soils are small, and soils are typically coarse textured [79] where water dominantly moves downwards and $\mathrm{P}$ is effectively retained in the B-horizon of podzol profile [13]. Next, we suggest that, when appropriate data are available, different peatland types and their fertility could be also analysed separately to improve the assessment of TN and TP export from boreal forests. It also seems that peatland and mineral soil fertility class should not be overlooked in models and they should be considered together with the intensity of management operations.

Though statistical comparison showed that TN and TP concentrations and exports were higher in managed than unmanaged catchments, this was not observed in the mixed effect models, even though forest management practices have been found, e.g., to increase $\mathrm{N}$ leaching $[80,81]$. In boreal catchments the organic fractions of $\mathrm{N}$ and $\mathrm{P}$ dominate the export, and the export of the organic fractions is mostly governed by natural sources, such as peatlands [50]. Especially in peatland dominated catchments, the management covering a small share of the catchment at the time can easily be masked behind the natural background exports.

Drainage intensity increased both TN and TP concentrations, following previous findings [24]. The $\mathrm{N}$ cycle is strongly affected by management such as drainage and clearcutting 
that affect through decreased plant nutrient uptake, enhanced mineralization and leaching, and increased denitrification [82,83]. Increased $\mathrm{N}$ leaching may last 10-15 years after clear-cutting $[9,84]$. Likewise, it has been discovered that TN and TP concentrations are much higher among drained peat-dominated catchments in comparison with unmanaged (undrained) peatlands [21]. We suppose that the effect of drainage on $\mathrm{N}$ and $\mathrm{P}$ concentrations is related to increased nutrient mineralization and aerobic decomposition of the organic surface layers [64]. Moreover, the results of the present study are consistent with Nieminen et al. [21,85] in suggesting that peatland drainage is at least in part responsible for the increased TN and TP export from boreal forests.

\section{Conclusions}

This study covered overall 30 catchments across Finland, producing a geographically encompassing survey of water quality in both unmanaged and managed boreal forested catchments. Responsible forest management requires knowledge of how and why water quality varies between different catchments. On average TN and TP exports were about two times higher in managed than in unmanaged catchments. While the biogeochemical mechanisms underlying $C$ and nutrient export cannot be resolved with the catchment level monitoring, we were able to identify the dominant natural and anthropogenic factors contributing to water quality. The results should be applicable to forest-dominated catchments in similar geologic and climatic conditions. In addition, the increasing effect of temperature sum on nutrient export and concentrations shows also that global warming may present us with new challenges in water protection in the future. Our models show that including soil and peatland fertility classes may provide additional information of the controls of nutrient export. We conclude that while it is difficult to isolate causal mechanisms and their interactions from the regression approach, the relatively simple and readily available catchment characteristics and climate variables identified in this study can be very helpful in assessing $C$ and nutrient export from different boreal forested catchments. The obtained models provide information on the most important factors affecting the concentrations and exports in boreal catchment areas. Thus, these models may be utilized to identify risk areas and to estimate the dependence of export of catchment characteristics and location.

Supplementary Materials: The following are available online at https:/ /www.mdpi.com/article/ 10.3390/w13172363/S1, Table S1: Catchment characteristics of unmanaged and managed boreal catchments used in the study. Figure S1: The correlations of fixed factors used in the models, Figure S2: Residual plots of final models.

Author Contributions: Conceptualization: L.F., T.T., S.T., T.M., S.P. and A.O.; methodology: T.T., S.L. A.L. and H.A.; validation: T.T., S.L.; formal analysis: H.A., T.T., S.L., A.L. and M.P.; data curation: A.L., S.L., T.T. and L.F.; writing—original draft preparation: H.A. and T.T.; writing—review and editing: T.T., M.P., A.L., S.T., S.P., T.M., A.O., S.L. and L.F. All authors have read and agreed to the published version of the manuscript.

Funding: This research was funded by the Ministry of Agriculture and Forestry (Finland) and the Academy of Finland (Reform water project (326818) and Cascas project $(323997,323998)$.

Data Availability Statement: The water quality monitoring data are updated on an annual basis and are freely available at http:/ / kartta.luke.fi/vesidata/, accessed on 2 August 2021.

Acknowledgments: The authors would like to thank Kristian Karlsson for support and advice on data analysis. The GIS data used in the study were produced and provided by the Natural Resources Institute Finland, Finnish Meteorological Institute, Geological Survey of Finland, and the National Land Survey of Finland.

Conflicts of Interest: The authors declare no conflict of interest. 


\section{References}

1. Carignan, R.; D'Arcy, P.; Lamontagne, S. Comparative impacts of fire and forest harvesting on water quality in Boreal Shield lakes. Can. J. Fish. Aquat. Sci. 2011, 57, 105-117. [CrossRef]

2. Minkkinen, K.; Korhonen, R.; Savolainen, I.; Laine, J. Carbon balance and radiative forcing of Finnish peatlands 1900-2100-The impact of forestry drainage. Glob. Chang. Biol. 2002, 8, 785-799. [CrossRef]

3. Schelker, J.; Eklöf, K.; Bishop, K.; Laudon, H. Effects of forestry operations on dissolved organic carbon concentrations and export in boreal first-order streams. J. Geophys. Res. Biogeosci. 2012, 117. [CrossRef]

4. Diodato, N.; Esposito, L.; Bellocchi, G. A First Regional-Scale Estimate of Climate-Driven Terrestrial Carbon Export in Boreal Catchments. Climate 2018, 6, 22. [CrossRef]

5. Bormann, F.H.; Likens, G.E.; Fisher, D.W.; Pierce, R.S. Nutrient Loss Accelerated by Clear-Cutting of a Forest Ecosystem. Science 1968, 159, 882-884. [CrossRef]

6. Ahtiainen, M. The effects of forest clear-cutting and scarification on the water quality of small brooks. Hydrobiologia 1992, 243, 465-473. [CrossRef]

7. Nieminen, M. Export of dissolved organic carbon, nitrogen and phosphorus following clear-cutting of three Norway spruce forests growing on drained peatlands in southern Finland. Silva Fenn. 2004, 38, 123-132. [CrossRef]

8. Laurén, A.; Heinonen, J.; Koivusalo, H.; Sarkkola, S.; Tattari, S.; Mattsson, T.; Ahtiainen, M.; Joensuu, S.; Kokkonen, T.; Finér, L. Implications of Uncertainty in a Pre-treatment Dataset when Estimating Treatment Effects in Paired Catchment Studies: Phosphorus Loads from Forest Clear-cuts. Water Air Soil Pollut. 2009, 169, 251-261. [CrossRef]

9. Palviainen, M.; Finér, L.; Laurén, A.; Launiainen, S.; Piirainen, S.; Mattsson, T.; Starr, M. Nitrogen, Phosphorus, Carbon, and Suspended Solids Loads from Forest Clear-Cutting and Site Preparation: Long-Term Paired Catchment Studies from Eastern Finland. AMBIO 2014, 43, 218-233. [CrossRef] [PubMed]

10. Kortelainen, P.; Saukkonen, S. Leaching of nutrients, organic carbon and iron from Finnish forestry land. Water Air Soil Pollut. 1998, 105, 239-250. [CrossRef]

11. Laudon, H.; Hedtjärn, J.; Schelker, J.; Bishop, K.; Sørensen, R.; Ågren, A. Response of dissolved organic carbon following forest harvesting in a boreal forest. AMBIO A J. Hum. Environ. 2009, 38, 381-386. [CrossRef]

12. Kortelainen, P.; Saukkonen, S.; Mattsson, T. Leaching of nitrogen from forested catchments in Finland. Glob. Biogeochem. Cycles 1997, 11, 627-638. [CrossRef]

13. Piirainen, S.; Finér, L.; Mannerkoski, H.; Starr, M. Carbon, nitrogen and phosphorus leaching after site preparation at a boreal forest clear-cut area. For. Ecol. Manag. 2007, 243, 10-18. [CrossRef]

14. Vaahtera, E.; Aarne, M. Finnish Forest Statistics; Natural Resources institute Finland: Helsinki, Finland, 2018,.

15. Joensuu, S.; Ahti, E.; Vuollekoski, M. Discharge water quality from old ditch networks in Finnish peatland forests. SUO 2001, $52,1-15$.

16. Manninen, N.; Soinne, H.; Lemola, R.; Hoikkala, L.; Turtola, E. Effects of agricultural land use on dissolved organic carbon and nitrogen in surface runoff and subsurface drainage. Sci. Total Environ. 2018, 618, 1519-1528. [CrossRef] [PubMed]

17. Åström, M.; Aaltonen, E.K.; Koivusaari, J. Effect of ditching operations on stream-water chemistry in a boreal forested catchment. Sci. Total Environ. 2001, 279, 117-129. [CrossRef]

18. Joensuu, S.; Ahti, E.; Vuollekoski, M. Effects of ditch network maintenance on the chemistry of run-off water from peatland forests. Scand. J. For. Res. 2002, 17, 238-247. [CrossRef]

19. Nieminen, M.; Ahti, E.; Koivusalo, H.; Mattsson, T.; Sarkkola, S.; Laurén, A. Export of suspended solids and dissolved elements from peatland areas after ditch network maintenance in south-central Finland. Silva Fenn. 2010, 44, 39-49. [CrossRef]

20. Finér, L.; Mattsson, T.; Joensuu, S.; Koivusalo, H.; Laurén, A.; Makkonen, T.; Nieminen, M.; Tattari, S.; Ahti, E.; Kortelainen, P. Metsäisten Valuma-Alueiden Vesistökuormituksen Laskenta; Finnish Environment Institute: Helsinki, Finland, 2010.

21. Nieminen, M.; Sallantaus, T.; Ukonmaanaho, L.; Nieminen, T.M.; Sarkkola, S. Nitrogen and phosphorus concentrations in discharge from drained peatland forests are increasing. Sci. Total Environ. 2017, 609, 974-981. [CrossRef]

22. Marttila, H.; Karjalainen, S.M.; Kuoppala, M.; Nieminen, M.L.; Ronkanen, A.K.; Kløve, B.; Hellsten, S. Elevated nutrient concentrations in headwaters affected by drained peatland. Sci. Total Environ. 2018, 643, 1304-1313. [CrossRef]

23. Mattsson, T.; Finér, L.; Kortelainen, P.; Sallantaus, T. Brook water quality and background leaching from unmanaged forested catchments in Finland. Water Air Soil Pollut. 2003, 147, 275-298. [CrossRef]

24. Finér, L.; Lepistö, A.; Karlsson, K.; Räike, A.; Härkönen, L.; Huttunen, M.; Joensuu, S.; Kortelainen, P.; Mattsson, T.; Piirainen, S.; et al. Drainage for forestry increases N, P and TOC export to boreal surface waters. Sci. Total Environ. 2021, 762, 144098. [CrossRef]

25. Ritson, J.; Croft, J.; Clark, J.; Brazier, R.; Templeton, M.; Smith, D.; Graham, N. Sources of dissolved organic carbon (DOC) in a mixed land use catchment (Exe, UK). Sci. Total Environ. 2019, 666, 165-175. [CrossRef] [PubMed]

26. Ågren, A.; Buffam, I.; Berggren, M.; Bishop, K.; Jansson, M.; Laudon, H. Dissolved organic carbon characteristics in boreal streams in a forest-wetland gradient during the transition between winter and summer. J. Geophys. Res. Biogeosci. 2008, 113. [CrossRef]

27. Arvola, L.; Räike, A.; Kortelainen, P.; Järvinen, M. The Effect of Climate and Landuse on TOC Concentrations and Loads in Finnish Rivers. Boreal Environ. Res 2004, 9, 381-387.

28. Kortelainen, P.; Mattsson, T.; Finér, L.; Ahtiainen, M.; Saukkonen, S.; Sallantaus, T. Controls on the export of C, N, P and Fe from undisturbed boreal catchments, Finland. Aquat. Sci. 2006, 68, 453-468. [CrossRef] 
29. Larsen, S.; Andersen, T.; Hessen, D.O. Predicting organic carbon in lakes from climate drivers and catchment properties. Glob. Biogeochem. Cycles 2011, 25, 3. [CrossRef]

30. Mattsson, T.; Kortelainen, P.; Räike, A. Export of DOM from boreal catchments: Impacts of land use cover and climate. Biogeochemistry 2005, 76, 373-394. [CrossRef]

31. Palviainen, M.; Finér, L.; Laurén, A.; Mattsson, T.; Högbom, L. A method to estimate the impact of clear-cutting on nutrient concentrations in boreal headwater streams. AMBIO 2015, 44, 521-531. [CrossRef]

32. Sebestyen, S.D.; Funke, M.; Cotner, J.B. Sources and biodegradability of dissolved organic matter in two headwater peatland catchments at the Marcell Experimental Forest, northern Minnesota, USA. Hydrol. Process. 2021, 35, e14049. [CrossRef]

33. Freeman, C.; Evans, C.; Monteith, D.; Reynolds, B.; Fenner, N. Export of organic carbon from peat soils. Nature 2001, $412,785$. [CrossRef]

34. Evans, C.; Monteith, D.; Cooper, D. Long-term increases in surface water dissolved organic carbon: Observations, possible causes and environmental impacts. Environ. Pollut. 2005, 137, 55-71. [CrossRef] [PubMed]

35. Gower, S.T.; McMurtrie, R.E.; Murty, D. Aboveground net primary production decline with stand age: Potential causes. Trends Ecol. Evol. 1996, 11, 378-382. [CrossRef]

36. Jansson, M.; Hickler, T.; Jonsson, A.; Karlsson, J. Links between terrestrial primary production and bacterial production and respiration in lakes in a climate gradient in subarctic Sweden. Ecosystems 2008, 11, 367-376. [CrossRef]

37. Ukonmaanaho, L.; Merilä, P.; Nöjd, P.; Nieminen, T.M. Litterfall production and nutrient return to the forest floor in Scots pine and Norway spruce stands in Finland. Boreal Environ. Res. 2008, 13, 67-91.

38. Stevens, P.; Norris, D.; Sparks, T.; Hodgson, A. The impacts of atmospheric N inputs on throughfall, soil and stream water interactions for different aged forest and moorland catchments in Wales. Water Air Soil Pollut. 1994, 73, 297-317. [CrossRef]

39. Rothe, A.; Mellert, K.H. Effects of Forest Management on Nitrate Concentrations in Seepage Water of Forests in Southern Bavaria, Germany. Water Air Soil Pollut. 2004, 156, 337-355. [CrossRef]

40. Dillon, P.J.; Molot, L.A.; Scheider, W.A. Phosphorus and Nitrogen Export from Forested Stream Catchments in Central Ontario. J. Environ. Qual. 1991, 20, 857-864. [CrossRef]

41. D'Arcy, P.; Carignan, R. Influence of catchment topography on water chemistry in southeastern Québec Shield lakes. Can. J. Fish Aquat. Sci. 1997, 54, 2215-2227. [CrossRef]

42. Mattsson, T.; Kortelainen, P.; Räike, A.; Lepistö, A.; Thomas, D.N. Spatial and temporal variability of organic C and N concentrations and export from 30 boreal rivers induced by land use and climate. Sci. Total Environ. 2015, 508, 145-154. [CrossRef] [PubMed]

43. Rekolainen, S.; Posch, M.; Kämäri, J.; Ekholm, P. Evaluation of the accuracy and precision of annual phosphorus load estimates from two agricultural basins in Finland. J. Hydrol. 1991, 128, 237-255. [CrossRef]

44. Mäkisara, K.; Katila, M.; Peräsaari, J.; Tomppo, E. The Multi-Source National Forest Inventory of Finland-Methods and Results 2013; Natural Resources Institute Finland: Helsinki, Finland, 2013

45. Bates, D.; Mächler, M.; Bolker, B.; Walker, S. Fitting Linear Mixed-Effects Models Using lme4. J. Stat. Softw. Artic. 2015, 67, 1-48. [CrossRef]

46. Hothorn, T.; Bretz, F.; Westfall, P. Simultaneous inference in general parametric models. Biom. J. Math. Methods Biosci. 2008, 50, 346-363. [CrossRef] [PubMed]

47. Akaike, H. A new look at the statistical model identification. IEEE Trans. Autom. Control 1974, 19, 716-723. [CrossRef]

48. Chambers, J.M.; Hastie, T.J. Statistical Models in S; Wadsworth \& Brooks: Pacific Grove, CA, USA, 1992.

49. Muukkonen, P.; Mäkipää, R. Empirical biomass models of understorey vegetation in boreal forests according to stand and site attributes. Boreal Environ. Res. 2005, 11, 355-369.

50. Palviainen, M.; Laurén, A.; Launiainen, S.; Piirainen, S. Predicting the export and concentrations of organic carbon, nitrogen and phosphorus in boreal lakes by catchment characteristics and land use: A practical approach. AMBIO 2016, 45, 933-945. [CrossRef]

51. Rantakari, M.; Mattsson, T.; Kortelainen, P.; Piirainen, S.; Finér, L.; Ahtiainen, M. Organic and inorganic carbon concentrations and fluxes from managed and unmanaged boreal first-order catchments. Sci. Total Environ. 2010, 408, 1649-1658. [CrossRef]

52. Lappalainen, M.; Palviainen, M.; Kukkonen, J.V.; Setälä, H.; Piirainen, S.; Sarjala, T.; Koivusalo, H.; Finér, L.; Launiainen, S.; Laurén, A. Release of carbon in different molecule size fractions from decomposing boreal mor and peat as affected by Enchytraeid worms. Water Air Soil Pollut. 2018, 229, 1-16. [CrossRef]

53. Päivänen, J. Hydraulic conductivity and water retention in peat soils. Acta For. Fenn. 1973. [CrossRef]

54. Tang, J.; Yurova, A.Y.; Schurgers, G.; Miller, P.A.; Olin, S.; Smith, B.; Siewert, M.B.; Olefeldt, D.; Pilesjö, P.; Poska, A. Drivers of dissolved organic carbon export in a subarctic catchment: Importance of microbial decomposition, sorption-desorption, peatland and lateral flow. Sci. Total Environ. 2018, 622, 260-274. [CrossRef] [PubMed]

55. Piirainen, S.; Finér, L.; Mannerkoski, H.; Starr, M. Effects of forest clear-cutting on the carbon and nitrogen fluxes through podzolic soil horizons. Plant Soil 2002, 239, 301-311. [CrossRef]

56. Tuukkanen, T.; Marttila, H.; Kløve, B. Predicting organic matter, nitrogen, and phosphorus concentrations in runoff from peat extraction sites using partial least squares regression. Water Resour. Res. 2017, 53, 5860-5876. [CrossRef]

57. Pastor, J.; Solin, J.; Bridgham, S.D.; Updegraff, K.; Harth, C.; Weishampel, P.; Dewey, B. Global warming and the export of dissolved organic carbon from boreal peatlands. Oikos 2003, 100, 380-386. [CrossRef] 
58. Davidson, E.A.; Janssens, I.A. Temperature sensitivity of soil carbon decomposition and feedbacks to climate change. Nature 2006, 440, 165-173. [CrossRef] [PubMed]

59. Hilasvuori, E.; Akujärvi, A.; Fritze, H.; Karhu, K.; Laiho, R.; Mäkiranta, P.; Oinonen, M.; Palonen, V.; Vanhala, P.; Liski, J. Temperature sensitivity of decomposition in a peat profile. Soil Biol. Biochem. 2013, 67, 47-54. [CrossRef]

60. Laurén, A.; Lappalainen, M.; Kieloaho, A.J.; Karhu, K.; Palviainen, M. Temperature sensitivity patterns of carbon and nitrogen processes in decomposition of boreal organic soils-Quantification in different compounds and molecule sizes based on a multifactorial experiment. PLoS ONE 2019, 14, e0223446. [CrossRef] [PubMed]

61. Sarkkola, S.; Koivusalo, H.; Laurén, A.; Kortelainen, P.; Mattsson, T.; Palviainen, M.; Piirainen, S.; Starr, M.; Finér, L. Trends in hydrometeorological conditions and stream water organic carbon in boreal forested catchments. Sci. Total Environ. 2009, 408, 92-101. [CrossRef]

62. Soja, A.J.; Tchebakova, N.M.; French, N.H.; Flannigan, M.D.; Shugart, H.H.; Stocks, B.J.; Sukhinin, A.I.; Parfenova, E.; Chapin, F.S., III; Stackhouse, P.W., Jr. Climate-induced boreal forest change: Predictions versus current observations. Glob. Planet. Chang. 2007, 56, 274-296. [CrossRef]

63. Lepistö, A.; Kortelainen, P.; Mattsson, T. Increased organic C and N leaching in a northern boreal river basin in Finland. Glob. Biogeochem. Cycles 2008, 22. [CrossRef]

64. Laurén, A.; Palviainen, M.; Launiainen, S.; Leppä, K.; Stenberg, L.; Urzainki, I.; Nieminen, M.; Laiho, R.; Hökkä, H. Drainage and Stand Growth Response in Peatland Forests-Description, Testing, and Application of Mechanistic Peatland Simulator SUSI. Forests 2021, 12, 293. [CrossRef]

65. Wickland, K.P.; Neff, J.C.; Aiken, G.R. Dissolved organic carbon in Alaskan boreal forest: Sources, chemical characteristics, and biodegradability. Ecosystems 2007, 10, 1323-1340. [CrossRef]

66. Heikkinen, K.; Karppinen, A.; Karjalainen, S.; Postila, H.; Hadzic, M.; Tolkkinen, M.; Marttila, H.; Ihme, R.; Kløve, B. Long-term purification efficiency and factors affecting performance in peatland-based treatment wetlands: An analysis of 28 peat extraction sites in Finland. Ecol. Eng. 2018, 117, 153-164. [CrossRef]

67. Lundin, L.; Bergquist, B. Effects on water chemistry after drainage of a bog for forestry. Hydrobiologia 1990, 196, 167-181. [CrossRef]

68. Valpasvuo-Jaatinen, P.; Rekolainen, S.; Latostenmaa, H. Finnish agriculture and its sustainability: Environmental impacts. AMBIO 1997, 26, 7, 448-455.

69. Cronan, C.S.; Piampiano, J.T.; Patterson, H.H. Influence of Land Use and Hydrology on Exports of Carbon and Nitrogen in a Maine River Basin. J. Environ. Qual. 1999, 28, 953-961. [CrossRef]

70. Sponseller, R.A.; Temnerud, J.; Bishop, K.; Laudon, H. Patterns and drivers of riverine nitrogen (N) across alpine, subarctic, and boreal Sweden. Biogeochemistry 2014, 120, 105-120. [CrossRef]

71. O’Driscoll, C.; Rodgers, M.; O'Connor, M.; de Eyto, E.; Poole, R.; Xiao, L. A potential solution to mitigate phosphorus release following clearfelling in peatland forest catchments. Water Air Soil Pollut. 2011, 221, 1-11. [CrossRef]

72. Laiho, R.; Laine, J. Nitrogen and phosphorus stores in Peatlands drained for forestry in Finland. Scand. J. For. Res. 1994, 9, 251-260. [CrossRef]

73. Richardson, C.J.; Marshall, P.E. Processes Controlling Movement, Storage, and Export of Phosphorus in a Fen Peatland. Ecol. Monogr. 1986, 56, 279-302. [CrossRef]

74. Cuttle, S.P. Chemical properties of upland peats influencing the retention of phosphate and potassium ions. J. Soil Sci. 1983, 34, 75-82. [CrossRef]

75. Zak, D.; Wagner, C.; Payer, B.; Augustin, J.; Gelbrecht, J. Phosphorus mobilization in rewetted fens: The effect of altered peat properties and implications for their restoration. Ecol. Appl. 2010, 20, 1336-1349. [CrossRef] [PubMed]

76. Koskinen, M.; Sallantaus, T.; Vasander, H. Post-restoration development of organic carbon and nutrient leaching from two ecohydrologically different peatland sites. Ecol. Eng. 2011, 37, 1008-1016. [CrossRef]

77. Dillon, P.J.; Molot, L.A. Effect of landscape form on export of dissolved organic carbon, iron, and phosphorus from forested stream catchments. Water Resour. Res. 1997, 33, 2591-2600. [CrossRef]

78. Sponseller, R.A.; Blackburn, M.; Nilsson, M.; Laudon, H. Headwater mires constitute a major source of nitrogen (N) to surface waters in the boreal landscape. Ecosystems 2018, 21, 31-44. [CrossRef]

79. Tamminen, P. Kangasmaan ravinnetunnusten ilmaiseminen ja viljavuuden alueellinen vaihtelu Etelä-Suomessa. Folia For. 1991, 777,40 .

80. Akselsson, C.; Westling, O.; Örlander, G. Regional mapping of nitrogen leaching from clearcuts in southern Sweden. For. Ecol. Manag. 2004, 202, 235-243. [CrossRef]

81. Schelker, J.; Sponseller, R.; Ring, E.; Högbom, L.; Löfgren, S.; Laudon, H. Nitrogen export from a boreal stream network following forest harvesting: Seasonal nitrate removal and conservative export of organic forms. Biogeosciences 2016, 13, 1-12. [CrossRef]

82. Wiklander, G.; Nordlander, G.; Andersson, R. Leaching of nitrogen from a forest catchment at söder sen in southern Sweden. Water Air Soil Pollut. 1991, 55, 263-282. [CrossRef]

83. Gundersen, P. Mass balance approaches for establishing critical loads for nitrogen in terrestrial ecosystems [nitrogen deposition]. In Proceedings of the Critical Loads for Nitrogen, Loekeberg, Sweden, 6-10 April 1992. 
84. Ahtiainen, M.; Huttunen, P. Long term effects of forestry managements on water quality and loading in brooks. Boreal Environ. Res. 1999, 4, 101-114.

85. Nieminen, M.; Sarkkola, S.; Sallantaus, T.; Hasselquist, E.M.; Laudon, H. Peatland drainage-a missing link behind increasing TOC concentrations in waters from high latitude forest catchments? Sci. Total Environ. 2021, 774, 145150. [CrossRef] 